Open Access

\title{
Accounting for tastes: do low-income populations have a higher preference for spicy foods?
}

\author{
Chao $\mathrm{Ma}^{1,2}$, Ze Song ${ }^{3^{*}}$, Xueling Yan $^{4}$ and Guangchuan Zhao ${ }^{5}$
}

\author{
*Correspondence: benz1985@163. \\ com \\ ${ }^{3}$ School of Economics, Nankai \\ University, Tianjin, China \\ Full list of author information is \\ available at the end of the article
}

\begin{abstract}
Based on the Theory of Rational Addiction (TORA), this paper uses the China Health and Nutrition Survey (CHNS) data to identify the correlation between income and preference for spicy foods. Results show that low-income individuals have a higher preference for spicy foods compared to high-income people, even in the same geographic area. Males and young people prefer spicy foods more than females and the elderly. Instrumental variable (IV) regression results also support that low-income individuals have a higher preference for spicy foods. The effect-channel results show that income affects the preference of spicy foods through health behaviors and health awareness. However, there is no significant evidence to support arguments about health capital stock and food selection channels.
\end{abstract}

Keywords: Spicy taste, Rational addiction, Health behaviors, Health awareness

\section{Introduction}

Spicy foods are considered a mainstay of dishes in China (Byrnes and Hayes 2013). Sichuan food is the most famous cuisine in China that is characterized by an extremely spicy taste. Conversely, Guangdong cuisine is rarely spicy. What factor determines individuals' preference for spicy foods? Sherman and Billing (1999) believe that climate variation is the main reason, which they call the climate hypothesis. According to Chinese historical records, it was widely accepted that capsicum had the capability to warm people and was thus used to alleviate the negative influences of moist and chilly climates. Consequently, spicy foods are healthful for residents in the southwest (e.g., Sichuan province) and northeast China, where the climate is moist or chilly. Due to the warm climate, people do not like spicy foods in southeast China (e.g., Guangdong province). ${ }^{1}$

However, evidences from ancient China and other countries around the world do not support the climate hypothesis. From a historical perspective, in Sichuan province, spicy foods were not as popular as they are today before the Qing Dynasty (A.D. 1644-1912). In the Tang and Song Dynasties (A.D. 618-1279), locals preferred sweet foods (Liang 2014). From a global perspective, spicy foods are extremely popular in India and Mexico (Mathew et al. 2000; López-Carrillo et al. 2003), where the climates are extremely hot. In northern Europe where the climate is cold, residents prefer

(c) The Author(s). 2018 Open Access This article is distributed under the terms of the Creative Commons Attribution 4.0 International License (http://creativecommons.org/licenses/by/4.0/), which permits unrestricted use, distribution, and reproduction in any medium, provided you give appropriate credit to the original author(s) and the source, provide a link to the Creative Commons license, and indicate if changes were made. 
non-spicy foods. It is worth mentioning that the intensity of the preference for spicy foods varies (Ahn et al. 2011; Ahn and Ahnert 2013).

Zhou (2014) argues that geographical proximity has a greater influence on dietary habits (hereafter geography hypothesis). Cultural exchange and integration occur more frequently between neighborhood areas, which cause similar taste preferences. For example, Sichuan cuisine is the result of cultural exchange and integration. Many residents actually immigrated from Hunan and Guangxi provinces to Sichuan province during the Qing Dynasty (Wu 2010). The spicy taste is popular in Hunan and Guangxi and was maintained in Sichuan cuisine since the Qing Dynasty (Liang 2014).

There is a flaw in the geography hypothesis, however. The shift in tastes occurred in the later Qing Dynasty, more than 100 years after the immigration flows and thus cannot be explained by the geography hypothesis. Based on the Directed Technical Change Model (Acemoglu 1998; Acemoglu 2002), Liang (2014) gives an explanation of the shift from an economic perspective. Condiments are the basic factors of production in cooking. The taste preference mainly depends on the most abundant condiment. The abundance of capsicum subsequently changed preferences of taste in Sichuan during the later Qing Dynasty. This hypothesis is known as the technique hypothesis (Liang 2014).

Whereas all above explanations are given from a macroscopic view, some researchers explain the formation of individual taste preferences from a microscopic view, e.g., social and cultural backgrounds (Rozin and Schiller 1980; Stevens 1990), repeated exposure to specific tastes (Logue and Smith 1986; Rozin 1990; Ludy and Mattes 2012), a genetic and physiological basis (Duffy and Bartoshuk 2000; Duffy 2007; Perry et al. 2007; Hayes et al. 2011), and individual personalities (Byrnes and Hayes 2013). Moreover, some researches show that food preference is a natural propensity (Cowart 1981; Duffy et al. 2009; IFICF 2012). These indicate that individual taste preferences are inherent or formed passively, and people cannot make a deliberate choice. It is the so-called De Gustibus Non EstDisputandum. ${ }^{2}$

The above explanations are far from satisfactory. Stigler and Becker (1977) claim that taste preferences are correlated with social-economic status. They think that personal social-economic conditions can influence individuals' behaviors and play an important role in the formation of taste preferences. Becker and Murphy (1988) develop the theory and propose the Theory of Rational Addiction (TORA). Some facts suggest that income may play a key role in determining individual taste preferences. Firstly, compared to Nordics, Indians and Mexicans have a lower income level and higher preference for spicy foods. Secondly, residents have lower per capita income and consume more spicy foods in China (Table 1). Thirdly, street foods are spicier than foods served in luxury restaurants. ${ }^{3}$ However, there are few empirical researches about how income affects spicy taste preference.

Based on Becker's theory, this paper uses the China Health and Nutrition Survey (CHNS) data to identify whether low-income individuals prefer spicy foods more than high-income people. It aims to provide new supplemental evidence to the TORA and Becker's concept "Accounting for Tastes" (Becker and Murphy 1988). Most quantitative studies on the preference of spicy foods are about medical and health (e.g., RamirezVictoria et al. 2001) and focus on the correlation rather than the causal relationship (Byrnes and Hayes 2013; Lv et al. 2015).This study uses empirical method to identify the causal relationship. As previously mentioned in a footnote, there is much debate 


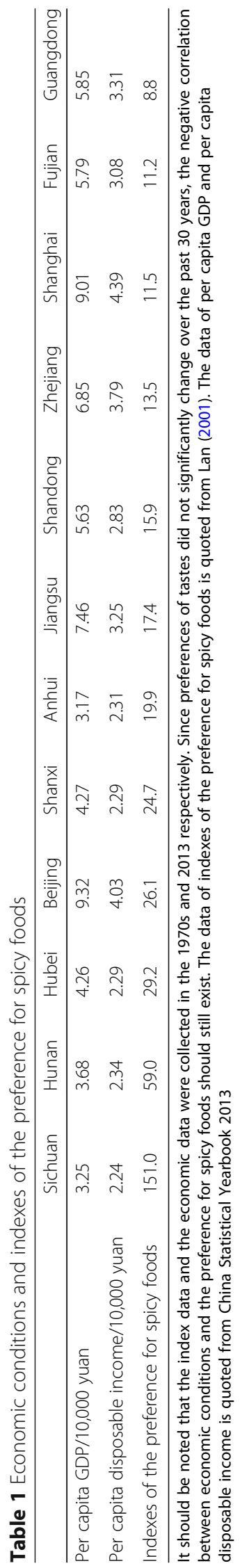


about whether low-income populations have a stronger preference for spicy foods, but the debate lacks detailed examination. Our research will provide empirical evidence to the question. The results show that low-income residents do have a greater preference for spicy foods in China. These results remain robust when other potential factors are controlled. Health behaviors and health awareness are the main reasons that low-income residents prefer spicy foods, and there is no significant evidence indicating that health capital stock and food selection have the same effect.

\section{Theory and method}

\section{Theory}

Becker and Murphy (1988) develop a theory of rational addiction in which rationality means a consistent plan to maximize utility over time. Utility of an individual at any moment depends on the consumption of two goods, the consumption of non-addictive goods $Y(t)$ and addictive goods $C(t)$. These goods are distinguished by assuming that current utility also depends on a measure of past consumption of $c$ but not of $y$.

The utility function is:

$$
U(0)=\int_{0}^{T} e^{-\sigma t} U[Y(t), C(t), S(t)] d t
$$

where $U(0)$ is the discounted maximized utility in a specific period and $\sigma$ represents a constant rate of time preference. In period $t$, individual utility depends on the consumption of non-addictive goods $Y(t)$, the consumption of addictive goods $C(t)$, and the total consumption of addictive goods before $t S(t)$. Due to the reinforcement effect, $U_{c s}$, the second derivative of $U$ with respect to $C$ and $S$, is greater than 0 , which means that the more addictive goods an individual consumed before the greater the margin effect of $C(t)$ will be. Due to the tolerance effect, a rational individual will recognize that consumption of a harmful good $\left(U_{\mathrm{s}}<0\right)$ will have negative effects on utility in the future while consumption of a beneficial good $\left(U_{\mathrm{s}}>0\right)$ will have positive effects on utility in the future. $U_{s}$ is the partial derivative of $U$ with respect to $S$. The change of $S$ satisfies Eq. (2):

$$
\dot{S}(t)=S(t)-S(t-1)=C(t)-\delta S(t)-h[D(t)]
$$

where $\dot{S}$ is the rate of change over time in $S$ and $C(t)$ is the consumption of addictive goods. The instantaneous depreciation rate $\delta$ represents the exogenous rate of disappearance of the physical and mental effects of consumption of $C$ in the past, and $D(t)$ represents expenditures on endogenous depreciation or appreciation.

Addictive consumption is considered a rational behavior and will definitely be affected by income (Becker and Murphy 1988). In this paper, spicy taste is a kind of addictive goods. To maximize utility over time, a rational agent will choose the optimal spicy taste based on income. If a spicy food is an inferior good, as income increases demand will decrease, whereas if a spicy food is a normal good, the correlation is difficult to determine. Since health is a normal good, if the cooking style of spicy foods is unhealthy, the relationship between income and the preference for spicy foods may be negative. Therefore, the relationship between income and taste is always an empirical question (Chaloupka 1991). 
Human behavior is not always absolutely rational. Personal cognitive limitations will limit individual choice. Based on Suranovic et al. (1999), the function including cognitive limitations is shown in Eq. (3):

$$
U_{t}(S)=B_{t}(S)+L_{t}(S)+C_{t}(S)
$$

where $B$ represents the current benefit from the addictive taste. $L$ represents the fully discounted future loss caused by the addictive taste, and $C$ represents the instant adjustment cost for changing the preference for the addictive taste.

For individuals, the loss of utility mainly occurs at or near the end of life and less at younger ages. Furthermore, when individuals shift from being less addicted to more addicted (formation of addiction), the instant adjustment cost is approximately 0 . In contrast, when individuals shift from more addicted to less addicted (alleviation of addiction), the instant adjustment cost is significantly greater than 0. Previous research indicates that spicy taste may be an unhealthy preference taste (e.g., Mathew et al. 2000; Archer and Jones 2002; López-Carrillo et al. 2012). With higher budget constraint, a high-income individual has better health behavior and health awareness and will avoid choosing spicy food (Dupas 2011). Therefore, health behaviors and health awareness may influence the preference for spicy foods through income level. This is discussed in detail in the following channel analysis.

To sum up, according to the TORA, the preference for spicy taste depends on income. For simplification, this paper exams whether income affects intensity of the preference for spicy foods and tests the channel effect of health behaviors and health awareness on the income-spicy nexus.

\section{Regression model}

The regression model is shown as:

$$
\text { Taste }_{i}=\alpha_{0}+\alpha_{1} \text { Income }_{i}+X_{i}^{\prime} \gamma+\mu_{i}
$$

where Taste ${ }_{i}$ represents the intensity of the preference for spicy foods and Income ${ }_{i}$ represents the individual income. $\alpha_{1}$ is the regression coefficient of Income, reflecting the causal relationship between income and the preference for spicy foods. $X_{i}$ is a set of control variables, including male, age, race, and so on. $\mu_{\mathrm{i}}$ is the residual.

To identify how income affects the preference for spicy foods through a pathway, the pathway variable $C_{i}$ was added into the regression, shown in Eq. (5):

$$
\text { Taste }_{i}=\beta_{0}+\beta_{1} \text { Income }_{i}+X_{i}^{\prime} \gamma+C_{i} \eta+\varepsilon_{i}
$$

Income can affect the preference for spicy foods through pathway $C_{i}$. The absolute value of the estimated value of $\beta_{1}$ (represented by $\hat{\beta}_{1}$ ) should be less than the absolute value of the estimated value of $\alpha_{1}$ (represented by $\left.\hat{\alpha}_{1}\right)$. Moreover, the significance ( $P$ value of the regression coefficient of Income) will decrease. According to the method proposed by Cutler and Lleras-Muney (2010), $1-\hat{\beta} / \hat{\alpha}$ was calculated, representing the proportion of effects directly caused by the pathway variable on the preference for spicy foods.

The possible channels are shown as follows. Firstly, lifestyles vary among different income groups. In comparison with the low-income individuals, high-income people 
usually have better health behaviors, such as doing more exercise and smoke less (Dupas 2011). Income may influence the preference for spicy foods via its influence on health behaviors. Secondly, high-income individuals usually have higher levels of health awareness and maintain healthy dietary habits (Stanton et al. 2016; Geaney et al. 2015). Thirdly, as an important human capital, the stock of health capital is positively correlated with income (Ettner 1996; Frijters et al. 2005). Since the preference for spicy foods is correlated with health, income may be correlated with the preference for spicy foods via its correlation with health capital stock. Fourthly, income has significant influence on food selection (Aguiar and Hurst 2005; Ma et al. 2009). Therefore, it is likely that compared to low-income people, high-income individuals prefer high-quality foods with less spicy taste.

\section{Instrumental variable}

Endogeneity is an unavoidable problem in this study. Firstly, endogeneity is from reverse causality and may have influence on health and thus have indirect influence on income. Secondly, omitted variables will cause endogeneity (e.g., genetic backgrounds, personalities, and so on), which may affect both income and taste preferences. Thirdly, measurement error can also lead to endogeneity. Endogeneity affects the identification of the relationship between income and the preference for spicy foods.

In order to solve endogeneity, this paper uses the logarithms of per capita house/ apartment values as an instrumental variable represented by $Z_{i}$. It is correlated with income and independent of taste preferences. Individuals with pleasant personalities may consume spicy foods more frequently (Byrnes and Hayes 2013). If individuals with pleasant personalities invest more money in houses/apartments, the instrumental variables will be inappropriate because the exclusion restriction is not satisfied. According to previous studies, individuals' genetic backgrounds can influence individual taste preferences (Hayes et al. 2011). If the genetic backgrounds are also correlated with preferences of properties, the instrumental variable will be inappropriate. Furthermore, if chili peppers are more readily available in low-income neighborhoods compared to high-income neighborhoods, these instrumental variables will be inappropriate. However, the possibilities of these situations are extremely low. The logarithms of per capita house/apartment values should satisfy the exclusion restriction and can be an appropriate instrumental variable.

In order to ensure its robustness, this paper also uses Lewbel's method (Lewbel 2012) to test the results. $X$ represents the exogenous variables shown in Eq. (4).

$$
\text { Income }_{i}=\alpha_{0}+\tilde{X}_{i} \gamma+v_{i}
$$

where $X$ includes age, male, marital status, employment, years of schooling, and other exogenous variables. Male and marital status are more independent of taste preferences. Thus, the two variables are considered exogenous variables, represented by $\tilde{X}_{i}$ $\cdot v_{i}$ is the residual. Both $\tilde{X}_{i}$ and $\left[Z_{i}-E\left(Z_{i}\right)\right] \cdot v_{i}$ can be used as instrumental variables. ${ }^{4}$

Based on Lewbel (2012), several conditions should be satisfied in advance. Firstly, $E$ ( $\left.\tilde{X}_{i} u_{i}\right)=0$. This means that all exogenous variables should be independent of residuals in Eqs. (4) and (6). We treat male and marital status as independent from taste preference. ${ }^{5}$ Secondly, $\operatorname{cov}\left(Z_{i}, u_{i} v_{i}\right)=0$. This is the exclusion restriction, which can be satisfied 
by the chosen instrumental variable. Thirdly, $\operatorname{cov}\left(Z_{i}, v_{i}^{2}\right) \neq 0$. This condition is relatively difficult to satisfy because the instrumental variable should simultaneously satisfy the exclusion restriction and be correlated with $v_{i}^{2}$.

\section{Data}

The China Health and Nutrition Survey (CHNS) was designed to examine the influences of social and economic transformations in China on individuals' nutrition, demographics, and health status. The CHNS has released nine waves of data so far (1989, 1991, 1993, 1997, 2000, 2004, 2006, 2009, and 2011). The question related to the preference for spicy foods only appears in wave 2009. The question asks, "What kind of spicy food do you like?" Three response options, "a little spicy," "moderate spicy," and "very spicy," were available. In the questionnaire, spicy taste is defined as containing hot pepper. The answer can be the proxy variables of the preference for spicy taste. Based on the self-reported preference for hot pepper, we define the level of the preference for spicy foods as the ordinal variable with the highest and lowest equal to three and one respectively.

In this research, we focus on per capita family income. The logarithms of per capita house/apartment values are used as the instrumental variable. After dropping missing samples, 5926 observations remain. Control variables include non-agricultural household registration status; married; male; age; years of schooling; employment; status of major chronic diseases including hypertension, diabetes, myocardial infarction, apoplexy, and asthma; awareness of the Dietary Guidelines; attitudes toward the priority of eating a healthy diet; average intakes of nutrients including energy, fat, and protein; and per capita house/apartment value. Table 2 shows the summary statistics.

\section{Empirical analysis}

\section{Preference for spicy foods and income}

OLS estimate

The statistical results show that the average of per capita income $(\log )$ is 8.63 in the group with the highest preference for spicy foods. The median preference group and lowest preference group are 8.826 and 8.864 respectively. Table 3 shows the regression results of the order logit regression (OLOGIT) (columns (1) and (3)) and the ordinary least squares (OLS) (columns (2) and (4)). Income has a significant negative effect on individual spicy taste. After controlling a series of variables, the negative effect is still robust. This means that the climate hypothesis and the geography hypothesis are inappropriate. $^{7}$ OLS results show the same income effect. The proxy variable of spicy taste is not a numerical variable. This paper pays attention to plus or minus of the coefficient and significance level. The OLS results are similar to OLOGIT, and OLS is more concise than OLOGIT. We only report the OLS results (Angrist and Pischke 2008). ${ }^{8}$ The results also show that coefficients of agricultural household registration, male, married, working, and young are significantly positive. This indicates that males and young people have a higher level of preference for spicy foods than females and the elderly. Compared to Liaoning Province, individuals from Jiangsu, Shandong, Henan, Hubei, and Guangxi Province prefer less spicy taste, whereas those from Hunan and 
Table 2 Summary statistics

\begin{tabular}{lllll}
\hline Variables & Means & Std. dev. & Min. & Max. \\
\hline Level of preference for spicy foods & 1.582 & 0.640 & 1 & 3 \\
PCI(log) & 8.828 & 1.256 & 0 & 12.612 \\
Household registration status & 0.392 & 0.488 & 0 & 1 \\
Marital status & 0.843 & 0.364 & 0 & 1 \\
Male & 0.503 & 0.500 & 0 & 1 \\
Age & 48.559 & 14.876 & 17.970 & 96.210 \\
Years of schooling & 7.720 & 4.190 & 0 & 18 \\
Employment & 0.886 & 0.843 & 0 & 3 \\
The status of major chronic diseases & & & & \\
$\quad$ Hypertension & 0.113 & 0.317 & 0 & 1 \\
$\quad$ Diabetes & 0.024 & 0.152 & 0 & 1 \\
$\quad$ Myocardial infarction & 0.006 & 0.080 & 0 & 1 \\
$\quad$ Apoplexy & 0.011 & 0.106 & 0 & 1 \\
$\quad$ Asthma & 0.011 & 0.105 & 0 & 1 \\
Smoking & 0.346 & 0.476 & 0 & 1 \\
Attitudes toward body building & 2.374 & 0.987 & 0 & 5 \\
Awareness of the Dietary Guideline & 0.137 & 0.344 & 0 & 1 \\
Attitudes toward the priority of eating a healthy diet & 3.240 & 0.757 & 1 & 5 \\
Average intake of nutrients & & & & 500,000 \\
$\quad$ Energy/kilocalories & 2234.233 & 1173.583 & 473.378 & $54,230.390$ \\
Fat/g & 78.921 & 108.474 & 1.508 & 5750.521 \\
$\quad$ Protein/g & 67.849 & 25.780 & 12.059 & 448.216 \\
Per capita house/apartment worth/yuan & $49,959.93$ & $62,719.7$ & 100 & \\
$N$ & 5964 & & & 1 \\
\hline
\end{tabular}

Guizhou Province prefer more spicy food. This supports the findings of geographical preference for spicy food in China (Lan 2001). ${ }^{9}$

\section{IV estimate}

The IV result is shown in Table 4. The first-stage result shows that there is a positive correlation between income and household value. The weak instruments variable test shows that the $F$ statistic is 225.137 , and $p$ value is 0 . This indicates that there is no weak instruments variable problem. The second-stage results suggest that higher income significantly weakens individuals' preference for spicy foods, and the coefficient value is greater than OLS. This means that the results underestimate the income negative effect on spicy taste in OLS. The results are significant at the $10 \%$ level, but the $p$ value is 0.055 , which is a little higher than 0.05 .

The result of Lewbel's IV is shown in Table 5. These IVs have stronger predictive power and are also plausibly excludable based on the tests of overidentification restrictions. These results also indicate that there is no weak instruments variable. The Hansen $J$ test does not reject the null hypothesis, which means that all instrumental variables are exogenous. The results show that higher income significantly weakens individuals' preference for spicy foods both in 2SLS and GMM. The coefficients are -0.0716 and -0.0732 
Table 3 Income and spicy preference

\begin{tabular}{|c|c|c|c|c|}
\hline & (1) & $(2)$ & (3) & (4) \\
\hline & OLOGIT & OLS & OLOGIT & OLS \\
\hline $\mathrm{PCl}(\log )$ & $-0.0371 * * *(0.0116)$ & $-0.0216^{* * *}(0.00670)$ & $-0.0289^{* *}(0.0126)$ & $-0.0164^{* *}(0.00697)$ \\
\hline $\begin{array}{l}\text { Household } \\
\text { registration status }\end{array}$ & & & $-0.103^{* * *}(0.0382)$ & $-0.0541^{* * *}(0.0195)$ \\
\hline Marital status & & & $0.149^{* * *}(0.0440)$ & $0.0754^{* * *}(0.0221)$ \\
\hline Male & & & $0.232^{* * *}(0.0321)$ & $0.120^{* * *}(0.0167)$ \\
\hline Age & & & $-0.00930^{* * *}(0.00132)$ & $-0.00479^{* * *}(0.000667)$ \\
\hline Years of schooling & & & $-0.00149(0.00507)$ & $-0.000934(0.00257)$ \\
\hline \multicolumn{5}{|l|}{ Locations } \\
\hline Heilongjiang & & & $0.125^{*}(0.0718)$ & $0.0665^{*}(0.0386)$ \\
\hline Jiangsu & & & $-0.329^{* * *}(0.0725)$ & $-0.163^{* * *}(0.0355)$ \\
\hline Shandong & & & $-0.186^{* * *}(0.0710)$ & $-0.0999 * * *(0.0360)$ \\
\hline Henan & & & $-0.160^{* *}(0.0753)$ & $-0.0832^{* *}(0.0385)$ \\
\hline Hubei & & & $-0.182^{* * *}(0.0702)$ & $-0.0951^{* * *}(0.0356)$ \\
\hline Hunan & & & $0.389^{* * *}(0.0630)$ & $0.210^{* * *}(0.0340)$ \\
\hline Guangxi & & & $-0.195^{* *}(0.0786)$ & $-0.0986^{* *}(0.0396)$ \\
\hline Guizhou & & & $0.440^{* * *}(0.0620)$ & $0.240^{* * *}(0.0334)$ \\
\hline \multicolumn{5}{|l|}{ Employment } \\
\hline Junior worker & & & $0.0939^{* *}(0.0387)$ & $0.0454^{* *}(0.0201)$ \\
\hline Senior worker & & & $0.144^{* *}(0.0573)$ & $0.0747^{* *}(0.0305)$ \\
\hline Manager & & & $0.279^{* * *}(0.0688)$ & $0.147^{* * *}(0.0378)$ \\
\hline Cons & & $1.773^{* * *}(0.0601)$ & & $1.811^{* * *}(0.0768)$ \\
\hline cut1 & $-0.326^{* * *}(0.104)$ & & $-0.415^{* * *}(0.142)$ & \\
\hline cut2 & $1.059^{* * *}(0.105)$ & & $1.041^{* * *}(0.143)$ & \\
\hline Observations & 5964 & 5964 & 5964 & 5964 \\
\hline
\end{tabular}

Standard errors are clustered in the county level (reported in parentheses). Liaoning is considered the reference for locations. Unemployment is considered the reference for employment

$* * * * *$, and $*$ indicate statistical significance at the $1 \%, 5 \%$, and $10 \%$ level respectively

Table 4 Results of instrumental variable

\begin{tabular}{lllll}
\hline & $(1)$ & $(2)$ & $(3)$ & $(4)$ \\
& $\begin{array}{l}\text { Preference for } \\
\text { spicy foods } \\
\text { OLS }\end{array}$ & $\begin{array}{l}\text { Logarithm of per } \\
\text { capita family income } \\
\text { First stage }\end{array}$ & $\begin{array}{l}\text { Preference } \\
\text { for spicy foods } \\
\text { IV-2SLS }\end{array}$ & $\begin{array}{l}\text { Preference for } \\
\text { spicy foods } \\
\text { IV-GMM }\end{array}$ \\
\hline PCI(log) & $-0.0164^{* *}(0.00697)$ & & $-0.0723^{*}(0.0377)$ & $-0.0723^{*}(0.0377)$ \\
PC house worth(log) & & $0.201^{* * *}(0.0134)$ & & \\
F statistics & 225.137 & & 5964 \\
Observations & 5964 & 5964 & 5964 & 5964 \\
\hline
\end{tabular}

Standard errors are clustered in the county level (reported in parentheses). Other controlled variables are the same as those shown in column (4) in Table 3

$* * * * *$, and $*$ indicate statistical significance at the $1 \%, 5 \%$, and $10 \%$ level respectively 
Table 5 Results of Lewbel's IV

\begin{tabular}{|c|c|c|c|c|}
\hline & (1) & (2) & (3) & (4) \\
\hline & $\begin{array}{l}\text { Preference } \\
\text { for spicy foods }\end{array}$ & $\begin{array}{l}\text { Preference } \\
\text { for spicy foods }\end{array}$ & $\begin{array}{l}\text { Preference } \\
\text { for spicy foods }\end{array}$ & $\begin{array}{l}\text { Preference } \\
\text { for spicy foods }\end{array}$ \\
\hline & OLS & IV & Lewbel-IV-2SLS & Lewbel-IV-GMM \\
\hline $\mathrm{PCI}(\log )$ & $-0.0164^{* *}(0.00697)$ & $-0.0723^{*}(0.0377)$ & $-0.0716^{* * *}(0.0201)$ & $-0.0732^{* * *}(0.0199)$ \\
\hline F statistics & & 225.137 & 255.248 & 255.248 \\
\hline Hansen & & & 0.120 & 0.120 \\
\hline Observations & 5964 & 5964 & 5964 & 5964 \\
\hline
\end{tabular}

Standard errors are clustered in the county level (reported in parentheses)

$*^{* *},{ }^{* *}$, and ${ }^{*}$ indicate statistical significance at the $1 \%, 5 \%$, and $10 \%$ level respectively

respectively. This also supports the previous results, which represent the income has negative effect on spicy taste.

\section{Path analysis}

Health behavior

Income is one of the key determinants of health behavior. Healthy behaviors differ significantly among various income groups (Dupas 2011). Mokdad et al. (2004) point out that the leading causes of death were tobacco (18.1\%), poor diet, and physical inactivity (16.6\%) in 2000. High-income and educated individuals smoke less and have a better lifestyle. Balia and Jones (2011) also note that there is a clear socioeconomic gradient in smoking initiation and cessation as well as on mortality. Jin and Jones-Smith (2014) indicate that children from lower income families have a less healthy physical fitness status. Individuals with good health habits eat healthier food(less spicy food). Therefore, we test the influence of health behaviors through whether one smokes and exercises. Table 6 shows that there is a positive correlation between smoking and preference for spicy foods. An individual who does exercises prefers less spicy food. This also indicates that individuals with a healthy lifestyle prefer less spicy foods. Controlling the healthy behavior variable, the coefficient of income decreases from - 0.0164 (column (4) of Table 3) to -0.0155 (column (1) of Table 6), and the $p$ value decreases from 0.020 to 0.027 . The value of $1-\hat{\beta} / \hat{\alpha}$ is $5.488 \%$, which means that healthy behavior can explain $5.488 \%$ of the correlation between income and spicy taste. In column (2), if we drop some observations with the answer "Does not participate" regarding doing exercises, the coefficient of income decreases from -0.0164 to -0.0145 (column (2) of Table 6), and healthy behavior can explain $11.585 \%$.

\section{Health awareness}

Health awareness is one of the key factors in the income-taste influencing mechanism. Kenkel (1991) believes that the variation in health awareness causes different health behaviors, and high-SES individuals have a higher level of health awareness. Stanton et al. (2016) and Geaney et al. (2015) find that there is a significant positive correlation between health awareness and healthy diet. Yoshioka et al. (2004) and Ludy and Mattes (2011) note that chili intake is closely linked with a healthy diet and eating too much chili can harm health. 
Table 6 Path analysis (1)

\begin{tabular}{|c|c|c|c|c|c|c|c|}
\hline & $(1)$ & (2) & (3) & (4) & $(5)$ & $(6)$ & (7) \\
\hline & $\begin{array}{l}\text { Health } \\
\text { behavior }\end{array}$ & $\begin{array}{l}\text { Health } \\
\text { behavior }\end{array}$ & $\begin{array}{l}\text { Health } \\
\text { awareness }\end{array}$ & $\begin{array}{l}\text { Health } \\
\text { capital } \\
\text { stock }\end{array}$ & $\begin{array}{l}\text { Food } \\
\text { selection }\end{array}$ & Total & Total \\
\hline $\mathrm{PCl}(\log )$ & $\begin{array}{l}-0.0155^{* *} \\
(0.00700)\end{array}$ & $\begin{array}{l}-0.0145^{* *} \\
(0.00709)\end{array}$ & $\begin{array}{l}-0.0155^{* *} \\
(0.00697)\end{array}$ & $\begin{array}{l}-0.0165^{* *} \\
(0.00699)\end{array}$ & $\begin{array}{l}-0.0166^{* *} \\
(0.00702)\end{array}$ & $\begin{array}{l}-0.0155^{* *} \\
(0.00706)\end{array}$ & $\begin{array}{l}-0.0143^{* * *} \\
(0.00714)\end{array}$ \\
\hline Smoking & $\begin{array}{l}0.0991^{* * *} \\
(0.0223)\end{array}$ & $\begin{array}{l}0.102^{* * *} \\
(0.0230)\end{array}$ & & & & $\begin{array}{l}0.0966^{* * *} \\
(0.0222)\end{array}$ & $\begin{array}{l}0.0990^{* * *} \\
(0.0230)\end{array}$ \\
\hline \multicolumn{8}{|c|}{ Attitude toward bodybuilding (Reference: dislike very much) } \\
\hline No attitude & $\begin{array}{l}-0.0668 \\
(0.0543)\end{array}$ & & & & & $\begin{array}{l}-0.0483 \\
(0.0553)\end{array}$ & \\
\hline Dislike & $\begin{array}{l}-0.00483 \\
(0.0365)\end{array}$ & $\begin{array}{l}0.0659 \\
(0.0433)\end{array}$ & & & & $\begin{array}{l}0.00468 \\
(0.0375)\end{array}$ & $\begin{array}{l}0.0568 \\
(0.0436)\end{array}$ \\
\hline Neutral & $\begin{array}{l}0.00556 \\
(0.0391)\end{array}$ & $\begin{array}{l}0.0764^{*} \\
(0.0457)\end{array}$ & & & & $\begin{array}{l}0.0209 \\
(0.0400)\end{array}$ & $\begin{array}{l}0.0734 \\
(0.0459)\end{array}$ \\
\hline Like & $\begin{array}{l}-0.0175 \\
(0.0414)\end{array}$ & $\begin{array}{l}0.0503 \\
(0.0476)\end{array}$ & & & & $\begin{array}{l}-0.000798 \\
(0.0422)\end{array}$ & $\begin{array}{l}0.0484 \\
(0.0479)\end{array}$ \\
\hline Like very much & $\begin{array}{l}-0.170^{*} \\
(0.0957)\end{array}$ & $\begin{array}{l}-0.101 \\
(0.0982)\end{array}$ & & & & $\begin{array}{l}-0.161^{*} \\
(0.0971)\end{array}$ & $\begin{array}{l}-0.116 \\
(0.0987)\end{array}$ \\
\hline Dietary Guideline & & & $\begin{array}{l}0.00693 \\
(0.0253)\end{array}$ & & & $\begin{array}{l}0.00883 \\
(0.0254)\end{array}$ & $\begin{array}{l}0.00951 \\
(0.0263)\end{array}$ \\
\hline \multicolumn{8}{|c|}{ Attitude toward the priority of eating a healthy diet (Reference: not important at all) } \\
\hline Not very important & & & $\begin{array}{l}-0.0188 \\
(0.0761)\end{array}$ & & & $\begin{array}{l}-0.0200 \\
(0.0770)\end{array}$ & $\begin{array}{l}-0.0419 \\
(0.0951)\end{array}$ \\
\hline Important & & & $\begin{array}{l}-0.157^{* *} \\
(0.0663)\end{array}$ & & & $\begin{array}{l}-0.156^{* *} \\
(0.0672)\end{array}$ & $\begin{array}{l}-0.189^{* *} \\
(0.0871)\end{array}$ \\
\hline Very important & & & $\begin{array}{l}-0.183^{* * *} \\
(0.0675)\end{array}$ & & & $\begin{array}{l}-0.180^{* * *} \\
(0.0685)\end{array}$ & $\begin{array}{l}-0.218^{* *} \\
(0.0881)\end{array}$ \\
\hline Most important & & & $\begin{array}{l}-0.140^{*} \\
(0.0788)\end{array}$ & & & $\begin{array}{l}-0.127 \\
(0.0803)\end{array}$ & $\begin{array}{l}-0.141 \\
(0.0977)\end{array}$ \\
\hline \multicolumn{8}{|c|}{ The status of major chronic diseases } \\
\hline Hypertension & & & & $\begin{array}{l}0.0323 \\
(0.0278)\end{array}$ & & $\begin{array}{l}0.0376 \\
(0.0278)\end{array}$ & $\begin{array}{l}0.0427 \\
(0.0287)\end{array}$ \\
\hline Diabetes & & & & $\begin{array}{l}0.0136 \\
(0.0499)\end{array}$ & & $\begin{array}{l}0.0181 \\
(0.0500)\end{array}$ & $\begin{array}{l}0.0260 \\
(0.0512)\end{array}$ \\
\hline Myocardial infarction & & & & $\begin{array}{l}0.0990 \\
(0.122)\end{array}$ & & $\begin{array}{l}0.105 \\
(0.123)\end{array}$ & $\begin{array}{l}0.113 \\
(0.133)\end{array}$ \\
\hline Apoplexy & & & & $\begin{array}{l}-0.123^{*} \\
(0.0660)\end{array}$ & & $\begin{array}{l}-0.133^{* *} \\
(0.0655)\end{array}$ & $\begin{array}{l}-0.145^{* *} \\
(0.0664)\end{array}$ \\
\hline Asthma & & & & $\begin{array}{l}-0.0158 \\
(0.0812)\end{array}$ & & $\begin{array}{l}-0.0304 \\
(0.0815)\end{array}$ & $\begin{array}{l}-0.0331 \\
(0.0825)\end{array}$ \\
\hline \multicolumn{8}{|c|}{ Average intake of nutrients } \\
\hline Energy & & & & & $\begin{array}{l}0.0000179 \\
(0.0000239)\end{array}$ & $\begin{array}{l}0.0000154 \\
(0.0000237)\end{array}$ & $\begin{array}{l}0.00000732 \\
(0.0000243)\end{array}$ \\
\hline Fat & & & & & $\begin{array}{l}-0.000232 \\
(0.000230)\end{array}$ & $\begin{array}{l}-0.000200 \\
(0.000227)\end{array}$ & $\begin{array}{l}-0.000129 \\
(0.000233)\end{array}$ \\
\hline Protein & & & & & $\begin{array}{l}0.000243 \\
(0.000489)\end{array}$ & $\begin{array}{l}0.000277 \\
(0.000485)\end{array}$ & $\begin{array}{l}0.000409 \\
(0.000498)\end{array}$ \\
\hline Cons & $\begin{array}{l}1.811^{* * *} \\
(0.0837)\end{array}$ & $\begin{array}{l}1.743^{* * *} \\
(0.0867)\end{array}$ & $\begin{array}{l}1.951^{* * *} \\
(0.102)\end{array}$ & $\begin{array}{l}1.816^{* * *} \\
(0.0770)\end{array}$ & $\begin{array}{l}1.773^{* * *} \\
(0.0816)\end{array}$ & $\begin{array}{l}1.910^{* * *} \\
(0.108)\end{array}$ & $\begin{array}{l}1.896^{* * *} \\
(0.127)\end{array}$ \\
\hline Observations & 5964 & 5604 & 5964 & 5964 & 5964 & 5964 & 5604 \\
\hline
\end{tabular}

Standard errors are clustered in the county level (reported in parentheses) $* * * * *$, and $*$ indicate statistical significance at the $1 \%, 5 \%$, and $10 \%$ level respectively 
The CHNS asks respondents whether they know the Dietary Guidelines and "How important is eating a healthy diet in your life?" There are five responses to the second question: "Not important at all," "Not very important," "Important," "Very important," or "The most important." Controlling the healthy behavior variable, the coefficient of income decreases from -0.0164 (column (4) of Table 3) to -0.0155 (column (3) of Table 6), and the $p$ value decreases from 0.020 to 0.027 . The value of $1-\hat{\beta} / \hat{\alpha}$ is $5.488 \%$. The results of health behavior and health cognition support the rational addiction framework with cognitive limitations (Suranovic et al. 1999).

\section{Health capital stock}

It is widely accepted that health capital stock can promote an increase in income (Ettner 1996; Frijters et al. 2005). Moreover, it has been noted that eating too much spicy food will increase health risks. Suffering from disease deteriorates health capital stock. CHNS includes a disease history question: "Has a doctor ever told you that you suffer from high blood pressure, diabetes, myocardial infarction, apoplexy, or asthma?"

After controlling the disease variable, we find that there are no significant changes in coefficient of income ( -0.0164 vs. -0.0165$)$ and significance level $(0.020$ vs. 0.018$)$ (see Table 6). The reason may be that eating spicy food does not directly increase the risks of these five chronic diseases. Some empirical research indicates that eating too much spicy food may increase the risk of gastric cancer, but there is insufficient gastric cancer information in CHNS to examine the effect of eating spicy food.

\section{Food selection}

In general, lower-income individuals have access to lower-quality ingredients, thus need to add more chili to improve the taste of the food (Aguiar and Hurst 2005; Ma et al. 2009). Aguiar and Hurst (2005) find that there is a difference among income groups in their patterns of nutrient intake. However, CHNS does not provide information about freshness and quality of ingredients. We cannot directly examine the mechanism of ingredients in the income-taste nexus. Since there is a correlation between nutrients and ingredients, we therefore examine whether nutrient intake will work in the incometaste nexus. Strauss (1986) and Pitt (1983) find that income is positively correlated with intakes of energy, protein, and fat. Adrian and Daniel (1976) argue that carbohydrates are a special energy substance, the consumption of which is correlated with income. Ma et al. (2009) argue that due to the income effect and the substitution effect of carbohydrates have mutually reversed effects on the consumption of carbohydrates, the correlation between income and the consumption of carbohydrates can be ambiguous. They also find that income is positively correlated with consumption of energy, protein, and fat. ${ }^{10}$ We therefore exam whether food selection plays a role in the relationship between income and preference for spicy foods.

Table 6 shows that there is no significant change in the coefficient of income and the significance level after controlling the food selection variable. There is no evidence to support the idea that income affects the preference for spicy foods via the pathway of food selection. Even though the data shows that the low-income population has a higher preference for spicy foods, there is no evidence to support Huang and Isaak (2015)'s argument. 
Table 7 Path analysis (2)

\begin{tabular}{llllllll}
\hline & $(1)$ & $(2)$ & $(3)$ & $(4)$ & $(5)$ & $(6)$ & $(7)$ \\
& OLS & IV & IV & IV & IV & IV & IV \\
\hline PCI(log) & $-0.0164^{* *}$ & $-0.0723^{*}$ & $-0.0676^{*}$ & $-0.0634^{*}$ & $-0.0731^{*}$ & $-0.0710^{*}$ & -0.0537 \\
& $(0.00697)$ & $(0.0377)$ & $(0.0380)$ & $(0.0382)$ & $(0.0387)$ & $(0.0395)$ & $(0.0393)$ \\
Health behavior & & & $\sqrt{ }$ & & & & $\sqrt{ }$ \\
Health awareness & & & & $\sqrt{ }$ & & & $\sqrt{ }$ \\
Health capital stock & & & & & $\sqrt{ }$ & & $\sqrt{ }$ \\
Food selection & & & & & & $\sqrt{ }$ & $\sqrt{ }$ \\
Observations & 5964 & 5964 & 5964 & 5964 & 5964 & 5964 & 5964 \\
\hline
\end{tabular}

Standard errors are clustered in the county level (reported in parentheses)

Note: ${ }^{* *},{ }^{* *}$, and ${ }^{*}$ indicate statistical significance at the $1 \%, 5 \%$, and $10 \%$ level respectively

\section{Pathway analysis based on IV}

The IV channel results show that the absolute values of the income coefficient decrease after controlling health behaviors. The values of $1-\hat{\beta} / \hat{\alpha}$ are $6.501 \%$ and $12.310 \%$ respectively. This means that healthy behaviors can explain $6.501 \%$ and $12.310 \%$ of income effect. There is no obvious change in the income coefficient after controlling disease history and nutrient intake. This indicates that the results of OLS are robust. When controlling all channels of influence variables, the proportion increases to 25.726\% (see Table 7).

\section{Conclusion}

This paper exams whether income determines individuals' preference for spicy foods. Previous researches focus on the preference for spicy foods from a macro perspective, such as the climate hypothesis, the geography hypothesis, and the technique hypothesis. Others pay attention to social and cultural backgrounds, repeated exposure to specific tastes, genetic and physiological basis, and individual personalities. According to Stigler and Becker (1977), personal economic conditions can influence individuals' behaviors and thus play an important role in the formation of taste preferences.

Based on the Theory of Rational Addiction (Becker and Murphy 1988), this paper finds that income has a significant negative effect on eating spicy food when controlling a series of demographic characteristic variables, especially regional variables. The results of IV and Lewbel's IV support the hypothesis that income decreases the propensity to consume spicy food. Health behaviors and health awareness can explain the income-taste influencing mechanism. This confirms the rational addiction framework with cognitive limitations (Suranovic et al. 1999). However, the variables of health capital stock and nutrient intake do not explain why lower-income individuals prefer eating spicy food.

This paper has some limitations. Firstly, due to the lack of more detailed data, it is impossible to distinguish among different spicy tastes caused by different condiments. Secondly, semi-quantitative variables are limited in describing the intensity of the preference for spicy food. Thirdly, this study only identifies that lower-income individuals have a higher preference for spicy food, but does not explain why and how the preference for spicy food is formed. 


\section{Endnotes}

${ }^{1}$ Generally, the spicy taste of foods is caused by capsaicin. Physiologically, capsaicin promotes energy metabolism, making people consume more energy substances to generate heat energy. After eating spicy foods, people feel warmer and tend to sweat (Lan 2001).

${ }^{2}$ De Gustibus Non EstDisputandum is a Latin proverb that means in matters of taste there can be no disputes. Stigler and Becker (1977) refute the idea in their influential paper that uses the proverb as the title.

${ }^{3}$ Huang and Isaak (2015) argue that in comparison with high-income individuals, low-income individuals cook relatively low-quality and low-nutrition food materials for lower prices. Low-income individuals have to add more chilies to improve the taste, but high-income individuals do not. After eating foods with spicy taste or non-spicy taste for a long period of time, people in different income groups form different taste preferences. This opinion has sparked much debate in China. Some people believe this explanation is reasonable, whereas others believe not and contend that it is a prejudice against those who prefer spicy foods.

${ }^{4}$ Detailed documentation can be found in Lewbel (2012). The command used in Stata is "ivreg2h," which has been discussed by Baum et al. (2012).

${ }^{5}$ It is impossible to ensure that an instrumental variable is absolutely independent of taste preferences. In practice, this restriction can be relaxed partly (Lewbel 2012). For example, some individual characteristics such as age and employment were used as $\tilde{X}_{i}$ in the Engel curve, and these variables were considered exogenous variables. We have done an overidentification test to exam the exogeneity. Details on this are given in the following part of the paper.

${ }^{6}$ Even though it is difficult to satisfy all the conditions, Lewbel (2012)'s method is helpful. Firstly, it may violate the exclusion restriction by using per capita house/apartment worth as the instrumental variable. Lewbel's method exams the exogeneity of the per capita house/apartment through the overidentification test. Secondly, the results are more robust, if Lewbel's IV is as same IV.

${ }^{7}$ Individuals' hometown information is likely to be more useful than current locations in regression. However, there is no relevant information in the CHNS database. It causes bias by immigration.

${ }^{8}$ The results are consistent between OLOGIT and OLS.

${ }^{9}$ When we control location in city level instead of province level, the result is still robust.

${ }^{10}$ These results are robust, but not the key in our paper. We do not discuss in detail.

Abbreviations

CHNS: China Health and Nutrition Survey; OLOGIT: Order logit regression; OLS: Ordinary least squares; TORA: Theory of Rational Addiction

Acknowledgements

We are grateful to Xi Chen (Yale University), Huang Wei (Harvard University), Liang Pinghan (Sun Yat-sen University), He Xiaobo (Shanghai University of International Business and Economics), Qu Zhaopeng (Nanjing University), Sun Xuhui (University College London), Li Jiajia (Shandong University), two anonymous referees, and the editor for their valuable comments. This paper has been improved by the comments of participants in the 2018 2nd Biennial Conference of CHPAMS (China Health Policy and Management Society) at Yale University. 


\section{Availability of data and materials}

The China Health and Nutrition Survey (CHNS) was designed to examine the effects of the health, nutrition, and family planning policies and programs implemented by national and local governments and to see how the social and economic transformation of Chinese society is affecting the health and nutritional status of its population. http://www.cpc.unc.edu/projects/china/data/datasets

\section{Authors' contributions}

$M C$ set the framework and did the main empirical work. SZ did parts of the empirical and wrote the main parts of paper. YX cleaned the data and wrote parts of the paper. ZG revised the grammar and sentences. All authors read and approved the final manuscript.

\section{Competing interests}

The authors declare that they have no competing interests,

\section{Publisher's Note}

Springer Nature remains neutral with regard to jurisdictional claims in published maps and institutional affiliations.

\section{Author details}

${ }^{1}$ School of Public Health, Southeast University, Nanjing, China. ${ }^{2}$ School of Public Health, Yale University, New Haven, USA. ${ }^{3}$ School of Economics, Nankai University, Tianjin, China. ${ }^{4}$ School of Economics, Sichuan University, Chengdu, China. ${ }^{5}$ School of Public Management, Nanjing University of Finance \& Economics, Nanjing, China.

Received: 3 August 2018 Accepted: 12 November 2018

Published online: 24 November 2018

\section{References}

Acemoglu, D. 1998. Why do new technologies complement skills? Directed technical change and wage inequality. The Quarterly Journal of Economics 113 (4): 1055-1089.

Acemoglu, D. 2002. Directed technical change. The Review of Economic Studies 69 (4): 781-809.

Adrian, J. and R. Daniel. 1976. Impact of Socioeconomic Factors on Consumption of Selected Food Nutrients in the United States. American Journal of Agricultural Economics 58 (1): 31-38.

Aguiar, M., and E. Hurst. 2005. Consumption versus expenditure. Journal of Political Economy 113 (5): 919-948.

Ahn, Y.-Y., and S. Ahnert. 2013. The flavor network. Leonardo 46 (3): 272-273.

Ahn, Y.-Y., S.E. Ahnert, J.P. Bagrow, and A.-L. Barabási. 2011. Flavor network and the principles of food pairing. Scientific Reports 1: 1-7.

Angrist, J.D., and J.-S. Pischke. 2008. Mostly harmless econometrics: an empiricist's companion. Princeton: Princeton University Press. Archer, V.E., and D.W. Jones. 2002. Capsaicin pepper, cancer and ethnicity. Medical Hypotheses 59 (4): 450-457.

Balia, S., and A.M. Jones. 2011. Catching the habit: a study of inequality of opportunity in smoking-related mortality. Journal of the Royal Statistical Society: Series A (Statistics in Society) 174 (1): 175-194.

Baum, C. F., A. Lewbel, M. E. Schaffer, and O. Talavera. Instrumental variables estimation using heteroskedasticity-based instruments. Type presented at the United Kingdom Stata User's Group Meetings, 2012.

Becker, G.S., and K.M. Murphy. 1988. A theory of rational addiction. Journal of Political Economy 96 (4): 675-700.

Byrnes, N.K., and J.E. Hayes. 2013. Personality factors predict spicy food liking and intake. Food Quality and Preference 28 (1): 213-221.

Chaloupka, F. 1991. Rational addictive behavior and cigarette smoking. Journal of Political Economy 99 (4): $722-742$.

Cowart, B.J. 1981. Development of taste perception in humans: sensitivity and preference throughout the life span. Psychological Bulletin 90 (1): 43.

Cutler, D.M., and A. Lleras-Muney. 2010. Understanding differences in health behaviors by education. Journal of Health Economics 29 (1): 1-28.

Duffy, V.B. 2007. Variation in oral sensation: implications for diet and health. Current Opinion in Gastroenterology 23 (2): $171-177$.

Duffy, V.B., and L.M. Bartoshuk. 2000. Food acceptance and genetic variation in taste. Journal of the American Dietetic Association 100 (6): 647-655.

Duffy, V.B., J.E. Hayes, B.S. Sullivan, and P. Faghri. 2009. Surveying food and beverage liking. Annals of the New York Academy of Sciences 1170 (1): 558-568

Dupas, P. 2011. Health behavior in developing countries. Annual Review of Economics 3 (1): 425-449.

Ettner, S.L. 1996. New evidence on the relationship between income and health. Journal of Health Economics 15 (1): 67-85.

Frijters, P., J.P. Haisken-DeNew, and M.A. Shields. 2005. The causal effect of income on health: evidence from German reunification. Journal of Health Economics 24 (5): 997-1017.

Geaney, F., S. Fitzgerald, J. Harrington, C. Kelly, B. Greiner, and I. Perry. 2015. Nutrition knowledge, diet quality and hypertension in a working population. Preventive Medicine Reports 2: 105-113.

Hayes, J.E., M.R. Wallace, V.S. Knopik, D.M. Herbstman, L.M. Bartoshuk, and V.B. Duffy. 2011. Allelic variation in TAS2R bitter receptor genes associates with variation in sensations from and ingestive behaviors toward common bitter beverages in adults. Chemical Senses 36 (3): 311-319.

Huang, Z.J., and I. Isaak. 2015. "Do the poor love spicy food and the rich love non-spicy food?" (in Chinese). China Folk (Popular Version) 1: 54-58.

IFICF. 2012. 2012 food \& health survey: Consumer attitudes towards food safety, nutrition \& health. www.foodinsight.org/ Content/5519/IFICF_2012_FoodHealthSurvey.pdf.

Jin, Y., and J. Jones-Smith. 2014. The relationship between family income and physical fitness and obesity of children (806.11). The FASEB Journal 28 (1 Supplement): 806-811.

Kenkel, D.S. 1991. Health behavior, health knowledge, and schooling. Journal of Political Economy 99 (2): 287-305. 
Lan, Y. 2001. "On the reasons and distrbution of pungent flavour in Chinese food and drink" (in Chinese). Human Geography 16 (5): 84-88.

Lewbel, A. 2012. Using heteroscedasticity to identify and estimate mismeasured and endogenous regressor models. Journal of Business \& Economic Statistics 30 (1): 67-80.

Liang, P.H. 2014. "Economic motivation of Chinese cuisine innovation: taking the development of Sichuan cuisine as an example" (in Chinese). Journal of Translation from Foreign Literature of Economics 3: 26-34.

Logue, A., and M.E. Smith. 1986. Predictors of food preferences in adult humans. Appetite 7 (2): 109-125.

López-Carrillo, L., M.C. Camargo, B.G. Schneider, L.A. Sicinschi, R.U. Hernández-Ramírez, P. Correa, and M.E. Cebrian. 2012.

Capsaicin consumption, Helicobacter pylori CagA status and IL1B-31C> T genotypes: a host and environment interaction in gastric cancer. Food and Chemical Toxicology 50 (6): 2118-2122.

López-Carrillo, L., M. López-Cervantes, G. Robles-Díaz, A. Ramírez-Espitia, A. Mohar-Betancourt, A. Meneses-García, Y. LópezVidal, and A. Blair. 2003. Capsaicin consumption, Helicobacter pylori positivity and gastric cancer in Mexico. International Journal of Cancer 106 (2): 277-282

Ludy, M.-J., and R.D. Mattes. 2011. The effects of hedonically acceptable red pepper doses on thermogenesis and appetite. Physiology \& Behavior 102 (3): 251-258.

Ludy, M.-J., and R.D. Mattes. 2012. Comparison of sensory, physiological, personality, and cultural attributes in regular spicy food users and non-users. Appetite 58 (1): 19-27.

Lv, J., L. Qi, C. Yu, L. Yang, Y. Guo, Y. Chen, Z. Bian, D. Sun, J. Du, and P. Ge. 2015. Consumption of spicy foods and total and cause specific mortality: population based cohort study. British Medical Journal 351: h3942.

Ma, S., L. Gan, and X.H. Gao. 2009. Analysis on the influence of 'income shock' on the nutritional structure in families: evidence from a natural experiment of higher education reform (in Chinese). Management World 5: 47-55.

Mathew, A., P. Gangadharan, C. Varghese, and M. Nair. 2000. Diet and stomach cancer: a case-control study in South India. European Journal of Cancer Prevention 9 (2): 89-98.

Mokdad, A.H., J.S. Marks, D.F. Stroup, and J.L. Gerberding. 2004. Actual causes of death in the United States, 2000. Jama 291 (10): 1238-1245.

Perry, G.H., N.J. Dominy, K.G. Claw, A.S. Lee, H. Fiegler, R. Redon, J. Werner, F.A. Villanea, J.L. Mountain, and R. Misra. 2007. Diet and the evolution of human amylase gene copy number variation. Nature Genetics 39 (10): 1256.

Pitt, M.M. 1983. Food preferences and nutrition in rural Bangladesh. The Review of Economics and Statistics: 105-114.

Ramirez-Victoria, P., J. Guzman-Rincon, J. Espinosa-Aguirre, and S. Murillo-Romero. 2001. Antimutagenic effect of one variety of green pepper (Capsicum spp.) and its possible interference with the nitrosation process. Mutation Research/Genetic Toxicology and Environmental Mutagenesis 496 (1): 39-45.

Rozin, P. 1990. Getting to like the burn of chili pepper: biological, psychological and cultural perspectives. Chemical Senses 2: $231-269$.

Rozin, P., and D. Schiller. 1980. The nature and acquisition of a preference for chili pepper by humans. Motivation and Emotion 4 (1): 77-101.

Sherman, P.W., and J. Billing. 1999. Darwinian gastronomy: why we use spices: spices taste good because they are good for us. BioScience 49 (6): 453-463.

Stanton, R., D. Scott, and B. Happell. 2016. Low knowledge of physical health behaviours is associated with poor diet and chronic illness in adults. Australian Journal of Primary Health 22 (3): 226-232.

Stevens, D. 1990. Personality variables in the perception of oral irritation and flavor. Chemical Senses 2: 217-228.

Stigler, G.J., and G.S. Becker. 1977. De gustibus non est disputandum. The American Economic Review 67 (2): 76-90.

Strauss, J. 1986. Does better nutrition raise farm productivity? Journal of Political Economy 94 (2): 297-320.

Suranovic, S.M., R.S. Goldfarb, and T.C. Leonard. 1999. An economic theory of cigarette addiction. Journal of Health Economics 18 (1): 1-29.

Wu, S.D. 2010. The migration of Sichuan people and changes of the acrid condiments. Journal of Henan University (Social Science) 1: 019.

Yoshioka, M., M. Imanaga, H. Ueyama, M. Yamane, Y. Kubo, A. Boivin, J. St-Amand, H. Tanaka, and A. Kiyonaga. 2004. Maximum tolerable dose of red pepper decreases fat intake independently of spicy sensation in the mouth. British Journal of Nutrition 91 (6): 991-995.

Zhou, T. 2014. "Analysis on the influence of geographical locations on dietary habits" (in Chinese). Journal of Translation from Foreign Literature of Economics 3: 35-37.

\section{Submit your manuscript to a SpringerOpen ${ }^{\circ}$ journal and benefit from:}

- Convenient online submission

- Rigorous peer review

- Open access: articles freely available online

- High visibility within the field

- Retaining the copyright to your article

Submit your next manuscript at $\boldsymbol{\nabla}$ springeropen.com 